\title{
Crescimento e nutrição mineral de milho forrageiro em cultivo hidropônico com soro de leite bovino
}

\author{
Leila de Paula ${ }^{1}$, Mário M. Rolim ${ }^{1}$, Egídio Bezerra Neto ${ }^{2}$, Tales M. Soares ${ }^{3}$, \\ Elvira M. R. Pedrosa ${ }^{1} \&$ Ênio F. de F. e Silva ${ }^{1}$
}

\begin{abstract}
RESU M 0
Realizou-se este trabalho com o objetivo de avaliar a eficiência nutricional da forragem de milho e a utilização do soro de leite bovino em substituição à solução nutritiva no cultivo de forragem hidropônica de milho. 0 experimento foi conduzido em casa de vegetação em delineamento experimental inteiramente casualizado, com seis tratamentos e cinco repetições, sendo o tratamento controle representado por solução nutritiva convencionalmente empregada nesse tipo de cultivo; os demais tratamentos foram distribuídos em diferentes níveis de diluição $(20,40,60,80$ e 100\%) do soro de leite em água potável. A colheita foi feita 15 dias após a germinação, separando-se a biomassa da parte aérea da biomassa do substrato com as raízes. Determinaram-se a massa fresca e seca, os teores de macronutrientes ( $N, P, K$, $\mathrm{Ca}, \mathrm{Mg}$ e S) e micronutrientes ( $\mathrm{Fe}, \mathrm{Cu}, \mathrm{Zn}$ e $\mathrm{Mn}$ ), além dos elementos em níveis tóxicos ( $\mathrm{Na}$ e $\mathrm{Cl}$ ), tanto da parte aérea como do sistema radicular. 0 aumento nas concentrações de soro de leite promoveu redução na produtividade da forragem hidropônica, acréscimo nos teores de $\mathrm{N}, \mathrm{S}$ e Zn, estabilidade no teor de $\mathrm{K}$ e redução do $\mathrm{Ca}$ e $\mathrm{Mg}$, não apresentando efeito nos teores de $\mathrm{P}, \mathrm{Fe}$ e $\mathrm{Cu}$, na parte aérea, enquanto nas raízes ocorreu acréscimo nos teores de $\mathrm{P}, \mathrm{K}, \mathrm{Ca}, \mathrm{Mg}, \mathrm{S}$ e $\mathrm{Cu}$.
\end{abstract}

Palavras-chave: Zea mays L., hidroponia, biofertilizante, aproveitamento de resíduos

\section{Growth and mineral nutrition of forage corn cultivated hydroponically with serum of cow milk}

\begin{abstract}
This research was accomplished with the objective of evaluating the nutritional efficiency of the use of serum of cow milk in substitution to the nutrient solution in hydroponic cultivation of forage corn. The experiment was carried out under greenhouse conditions in a completely randomized design with six treatments and five replications. The conventional nutrient solution was used as the control. The other treatments were distributed in different levels $(20,40,60,80$ and $100 \%)$ of milk serum dilution in drinking water. Corn plants were harvested 15 days after the germination, separating biomass of shoots from biomass of the substrate with the roots. The mass of fresh and dry matter, the macro $(\mathrm{N}, \mathrm{P}, \mathrm{K}, \mathrm{Ca}, \mathrm{Mg}$ and $\mathrm{S}$ ) and micronutrient ( $\mathrm{Fe}, \mathrm{Cu}, \mathrm{Zn}$ and $\mathrm{Mn}$ ) contents were evaluated, besides the elements in toxic levels ( $\mathrm{Na}$ and $\mathrm{Cl}$ ), in both shoots and substrate plus roots masses. Increase in milk serum concentration promoted reduction of hydroponic forage yield, increment in N, S and Zn, stability of K, reduction of Ca and $\mathrm{Mg}$, and no effect on $\mathrm{P}, \mathrm{Fe}$ and $\mathrm{Cu}$ contents in shoots. In root there was increase in $\mathrm{P}, \mathrm{K}, \mathrm{Ca}, \mathrm{Mg}$, S and $\mathrm{Cu}$.
\end{abstract}

Key words: Zea mays L., hydroponics, biofertilizer, residue use

\footnotetext{
${ }^{1}$ DTR/ U FRPE, Av. Dom Manuel de Medeiros, s/n, Dois Irmãos, CEP 52171-900, Recife, PE. Fone: (81) 3320-676. E-mail: leiladipaula@yahoo.com.br, rolim@dtr.ufrpe.br, enio.silva@dtr.ufrpe.br, elvira.pedrosa@dtr.ufrpe.br

2 DQ / UFRPE. Fone: (81) 3320-6367. E-mail: egidiobn@yahoo.com.br

3 NEAS/U FRB - CEP 44380-000, Cruz das Almas, BA. E-mail: talesmiler@gmail.com
} 


\section{INTRODUÇÃO}

A agricultura orgânica é baseada na aplicação de tecnologias não prejudiciais ao meio ambiente e reduz consideravelmente a necessidade da utilização de insumos externos, por não utilizar fertilizantes e defensivos químicos ou outros produtos industrializados (Gonella et al., 2002).

O soro do leite é o líquido resultante da separação da caseína e da gordura do leite no processo de elaboração do queijo, apresentando alto valor nutricional, com mais da metade dos sólidos presentes no leite integral original, incluindo a maior parte da lactose, minerais e vitaminas hidrossolúveis e cerca de $20 \%$ das proteínas do leite. Embora o soro de leite contenha substâncias de alto valor nutricional (Huraguchi et al., 2006; Silva et al., 2004), ainda é pouco aproveitado e grandes volumes são desperdiçados, sendo constituinte das águas residuárias advindas dos lacticínios e direcionado diretamente aos corpos receptores ou em sistemas de tratamento com baixa eficiência, contaminando drasticamente o meio ambiente, caracterizando grave impacto negativo das indústrias de laticínios no mundo (Hosseini et al., 2003).

O aproveitamento de resíduos orgânicos minimiza os efeitos devastadores que provocam ao meio ambiente (Fernandes \& Testezlaf, 2002). O soro de leite pode ser considerado um poluente extremamente problemático devido à sua elevada carga orgânica e grande volume gerado, devendo ser tratado antes de descartado, visto que o soro bruto possui uma demanda bioquímica de oxigênio (DBO) de 30.000 a $60.000 \mathrm{mg}$ $\mathrm{L}^{-1}$, sendo a lactose responsável por aproximadamente $90 \%$ da carga orgânica do soro (Ghaly \& Kamal, 2004; Florentino, 2004). Com uma DBO mais de 10 vezes superior ao esgoto doméstico bruto, 250 a $350 \mathrm{mg} \mathrm{L}^{-1}$, o soro é um dos mais poluentes de todos os efluentes. Além da poluição ambiental, o descarte do soro é também um desperdício de material protéico e de outros nutrientes, uma vez que retém cerca de $55 \%$ dos nutrientes do leite (Almeida et al., 2001).

A identificação de alternativas para um aproveitamento adequado do soro de leite é de fundamental importância em função de sua qualidade nutricional, do seu volume e de seu poder poluente (Reis, 1999). Nesse caso, o ideal são alternativas sustentáveis que conciliem a redução do impacto ambiental à destinação nobre para o soro de leite, dentro de atividades econômicas atrativas.

Estudos recentes demonstram a possibilidade de aumento na produção agrícola com aproveitamento do soro do leite. Gheri et al. (2003), trabalhando com a utilização de soro no solo $\left(500 \mathrm{~m}^{3} \mathrm{ha}^{-1}\right)$ para produção de capim tanzânia, observaram não só aumento significativo no acúmulo de massa fresca dessa forrageira, sem registro de impacto ambiental em relação ao teor de nitrato no solo, mas também o aumento significativo na quantidade de nutrientes absorvidos, principalmente de $\mathrm{K}, \mathrm{Pe}$ Ca. Neste mesmo contexto, Santos et al. (2006) utilizaram o soro na ensilagem de capim elefante como fonte de bactérias láticas, visando melhorar o perfil de fermentação das silagens e verificaram menores valores de $\mathrm{pH}$ e $\mathrm{N}$-amoniacal nas silagens tratadas com soro não comprometendo, assim, a composição bromatológica da silagem.
O soro de leite pode ocasionar grandes desequilíbrios ao ambiente; no entanto, quando bem utilizado pode proporcionar benefícios. Brown et al. (1998) e Lehrsch et al. (2008), estudando a aplicação de soro de leite em sulcos de irrigação, verificaram efeito promissor do soro sobre o aumento na estabilidade de agregados e redução da erosão em um solo calcário estruturalmente degradado.

Não se tem registro de relatos da utilização de soro de leite como fertilizante orgânico no cultivo de forragem hidropônica, embora a destinação de águas residuárias para a hidroponia venha sendo investigada como alternativa produtiva, possível de aliar a produção agrícola, com a possibilidade de um controle ambiental maior (Soares et al., 2006; Keller et al., 2008; Santos et al., 2010; Gomes et al., 2011). Em se tratando do aproveitamento dessas águas, a precocidade e a rapidez no crescimento vegetal são características desejáveis, uma vez que um tempo menor de exposição implica em menor absorção e acúmulo de íons nas plantas (Soares et al., 2010); tal precocidade é benéfica para o melhor aproveitamento do soro de leite, considerando-se sua elevada DBO e a depreciação da qualidade da solução nutritiva.

Nesse contexto, a produção de forragem hidropônica se destaca pela possibilidade de se produzir um alimento altamente nutritivo e em curto espaço de tempo, empregando-o na dieta animal da mesma cadeia produtiva de queijos (FAO, 2001; Amorim et al., 2005; Muller et al., 2006a, b). Na hidroponia, as soluções nutritivas provenientes de fertilizantes químicos industriais, de elevado custo, dificultam a adoção da técnica pelos produtores menos capitalizados ou interessados em sistemas orgânicos de produção, o que tem conduzido aos estudos envolvendo soluções nutritivas orgânicas (Villela Júnior et al., 2003; Dias et al., 2009). Considerando a composição química do soro de leite, supõe-se que esse efluente pode ser empregado em cultivos hidropônicos, como componente ou mesmo substituto alternativo de soluções nutritivas convencionalmente preparadas com fertilizantes químicos. $\mathrm{Na}$ literatura pertinente não há relatos da utilização de soro de leite como fertilizante orgânico no cultivo de forragem hidropônica; portanto, objetivou-se no presente trabalho avaliar a produção e a composição de forragem hidropônica de milho utilizando diferentes diluições de soro de leite como solução nutritiva.

\section{Material e MÉTOdos}

O experimento foi conduzido no período de 17 de fevereiro a 04 de março de 2009, em casa de vegetação, no Departamento de Tecnologia Rural da Universidade Federal Rural de Pernambuco (UFRPE), Recife, PE.

O delineamento experimental adotado foi inteiramente casualizado, com seis tratamentos e cinco repetições. O tratamento usado como testemunha foi uma solução nutritiva (Tabela 1) usualmente empregada para forragem de milho hidropônico; os demais tratamentos constaram de níveis de diluição do soro de leite em água de abastecimento, quais sejam: $20,40,60,80$ e $100 \%$ de soro. 
Tabela 1. Composição química das soluções referentes aos tratamentos, do substrato (bagaço de cana) e de semente de milho utilizada no cultivo do milho hidropônico

\begin{tabular}{|c|c|c|c|c|c|c|c|c|c|c|c|c|c|}
\hline \multirow{2}{*}{$\begin{array}{l}\text { Tratamentos } \\
\text { (\% de soro de leite })^{1}\end{array}$} & $\mathbf{N}$ & $\mathbf{P}$ & $K$ & $\mathrm{Ca}$ & $\mathrm{Mg}$ & 5 & $\mathrm{Na}$ & $\mathrm{Fe}$ & $\mathrm{Cu}$ & $\mathrm{Mn}$ & $\mathrm{Zn}$ & \multirow{2}{*}{$\begin{array}{c}\text { CE } \\
d S \text { m }^{-1}\end{array}$} & \multirow{2}{*}{$\mathrm{pH}$} \\
\hline & \multicolumn{7}{|c|}{$\mathrm{mg} \mathrm{L}^{-1}$} & \multicolumn{4}{|c|}{$\mu g \mathrm{~L}^{-1}$} & & \\
\hline Testemunha ${ }^{2}$ & 62 & 8,9 & 49,7 & 49,4 & 6,2 & 8,1 & - & 938 & 35 & 438 & 88 & 0,7 & 4,0 \\
\hline T-100 & 860 & 300 & 1500 & 220 & 180 & 127 & 370 & 80.000 & 2.000 & 2.000 & 2.400 & 5,5 & 4,1 \\
\hline T-80 & 688 & 240 & 1200 & 176 & 144 & 101 & 296 & 64.000 & 1600 & 1.600 & 1.920 & 4,4 & 4,1 \\
\hline T-60 & 516 & 180 & 900 & 132 & 108 & 76 & 222 & 48.000 & 1200 & 1.200 & 1.440 & 3,3 & 4,1 \\
\hline $\mathrm{T}-40$ & 344 & 120 & 600 & 88 & 72 & 51 & 148 & 32000 & 800 & 800 & 960 & 2,2 & 4,1 \\
\hline T-20 & 172 & 60 & 300 & 44 & 36 & 25 & 74 & 16000 & 400 & 400 & 480 & 1,1 & 4,1 \\
\hline Bagaço de cana & 3,14 & - & 0,35 & 0,86 & 0,23 & - & 0,35 & 202 & 30,63 & 6,93 & - & - & - \\
\hline Semente de milho & 10,99 & - & 3,54 & 1,02 & 0,88 & - & 0,18 & 110 & 36,22 & 6,94 & - & - & - \\
\hline
\end{tabular}

1 Diluído em água de abastecimento

${ }^{2}$ Solução nutritiva (Bezerra Neto \& Barreto, 2004)

O soro de leite utilizado foi proveniente da fabricação de queijo tipo coalho (soro ácido) a partir do processamento industrial do leite bovino, transportado em tambores de $50 \mathrm{~L}$ (sem refrigeração) e armazenado em freezer a $0{ }^{\circ} \mathrm{C}$, sendo retirado apenas no momento das regas.

O substrato empregado no cultivo hidropônico de milho foi o bagaço de cana-de-açúcar, escolhido por razão da sua disponibilidade regional e por ser recomendado para a produção hidropônica de forragem (Santin et al., 2005). O bagaço de canade-açúcar empregado como substrato foi triturado em máquina forrageira, peneirado, posto em reservatório com água corrente durante de $24 \mathrm{~h}$ para retirada de açúcar e evitar ataque de formigas; após este processo o material foi espalhado em lonas, em camadas finas e uniformes, para sua secagem; posteriormente, foram coletadas amostras para análise química do substrato (Tabela 1).

O sistema hidropônico foi disposto em trinta bandejas plásticas $(50 \times 35 \mathrm{~cm})$ posicionadas a $0,80 \mathrm{~m}$ de altura do solo, sobre bancadas de ferro, com uma inclinação de $4 \%$; adotouse o sistema hidropônico fechado, ou seja, com reaproveitamento das soluções dos tratamentos; as bandejas foram perfuradas na lateral, à qual se conectou uma mangueira, objetivando-se drenar as soluções irrigadas para os coletores (2 L de capacidade), os quais armazenavam o volume drenado a ser reutilizado na próxima irrigação.

Utilizaram-se sementes de milho não tratadas, uma vez que sementes quimicamente tratadas não são recomendadas para forragem hidropônica, considerando-se o risco de intoxicação para os animais (Amorim et al., 2005). A viabilidade dessas sementes foi previamente determinada através de um teste de germinação, em que as sementes foram postas em papel toalha e com ele cobertas, mantendo-as sempre úmidas pelo tempo de $48 \mathrm{~h}$; em seguida, o poder germinativo foi avaliado em cerca de $80 \%$; amostras de sementes foram utilizadas para as análises químicas, visando-se determinar seus teores dos nutrientes minerais (Tabela 1).

As sementes de milho foram selecionadas através da escolha manual; e posteriormente as selecionadas passaram pelo período de quebra de dormência, fase que corresponde à sua submersão em água, por $24 \mathrm{~h}$.

A densidade de semeadura foi de $2,5 \mathrm{~kg} \mathrm{~m}^{-2}$ (FAO, 2001); cada bandeja $\left(0,175 \mathrm{~m}^{2}\right)$ recebeu $400 \mathrm{~g}$ de sementes de milho, que foram distribuídas sobre uma camada de $80 \mathrm{~g}$ de substrato, dispostas uniformemente e cobertas com outra camada de $120 \mathrm{~g}$ de substrato. O período de germinação durou sete dias, sendo irrigadas durante esta fase em que as sementes foram irrigadas apenas com água potável, seis vezes ao dia $(8,10,12$, 14, 16 e 18 h); logo após a germinação iniciou-se a irrigação com solução nutritiva (tratamento controle) com soro de leite diluído, conforme tratamento; as irrigações foram realizadas manualmente, da mesma forma adotada na fase da germinação, sendo que em cada evento de irrigação foi tomada a precaução de não se deixar o soro de leite e a solução nutritiva entrarem em contato com as folhas, para evitar absorção e, por conseguinte, toxidez.

A colheita feita 15 dias após a germinação correspondeu a 21 dias após a semeadura; com o auxílio de uma tesoura, a parte aérea das plantas foi cortada rente ao substrato; posteriormente, obteve-se, em balança de precisão, a massa fresca da parte aérea (MFPA) e a massa fresca do substrato com as raízes (MFPR); três dias após a secagem em estufa com circulação forçada e temperatura controlada em $65^{\circ} \mathrm{C}$, foram obtidas as massas de matéria seca da parte aérea (MSPA) e do substrato com as raízes (MSPR); em seguida, as amostras secas foram trituradas em moinho tipo Willey para as determinações químicas (Bezerra Neto \& Barreto, 2004); preparou-se um extrato nitro-perclórico, no qual se determinou fósforo espectrofotometricamente, potássio e sódio por fotometria de chama e cálcio, magnésio, ferro, cobre, zinco e manganês em espectrofotômetro de absorção atômica; o nitrogênio foi determinado por arraste de vapor em extrato sulfúrico e o cloreto pelo método de Mohr em extrato aquoso.

Os resultados obtidos com as diferentes concentrações de soro de leite foram submetidos à análise de regressão, buscandose ajustar modelos de tendência; os modelos foram selecionados com base na significância indicada pelo teste $\mathrm{F}$ a $5 \%$ de probabilidade e nos valores dos coeficientes de correlação; a significância dos coeficientes do modelo ajustado foi avaliada pelo teste $\mathrm{t}$ em nível de $5 \%$ de probabilidade; também foram contrastados os resultados obtidos com a solução nutritiva convencional e com cada concentração de soro de leite diluído em água, mediante comparação de médias, pelo teste t. As análises estatísticas foram conduzidas no software SAS.

\section{RESULTADOS E DISCUSSÃO}

Constatou-se significância $(\mathrm{P}<0,01)$ nas variáveis: MFPA, MSPA, MFPR e $(P<0,05)$ na variável MSPR. As equações de 
regressão que melhor se ajustaram foram lineares para MFPA, MSPA, MSPR e quadrática para MFPR (Figura 1).

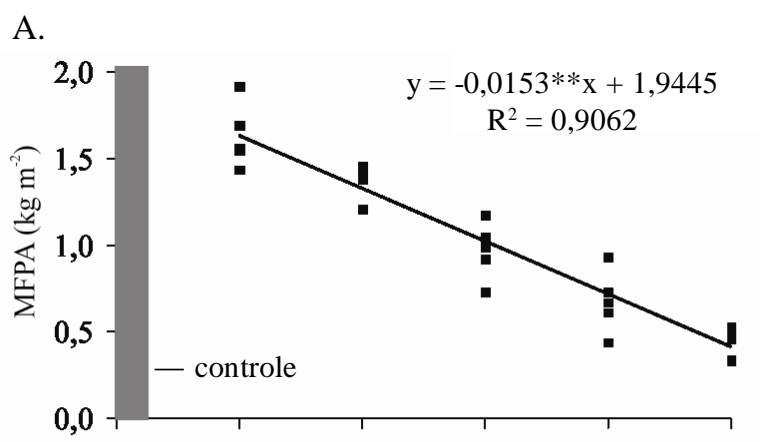

B.

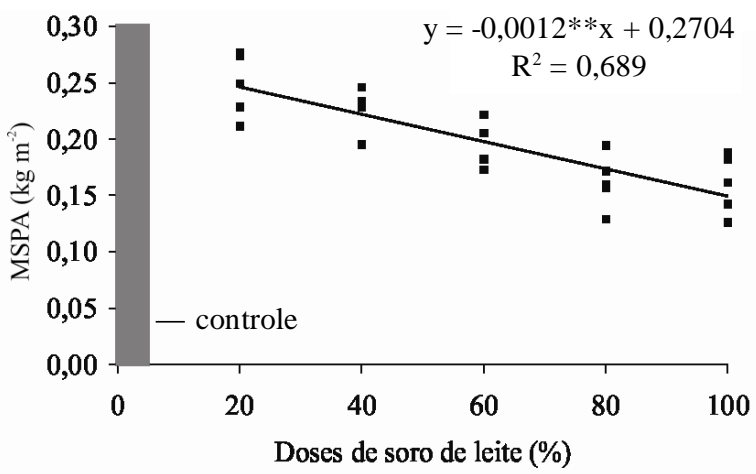

Figura 1. Massa fresca da parte aérea (MFPA) (A) e massa seca da parte aérea (MSPA) (B), de milho cultivado hidroponicamente em função de concentrações de soro de leite

O aumento das doses de soro de leite utilizadas como solução de cultivo levou à redução linear da produção de forragem de milho hidropônico, em termos de acúmulo de MFPA e de MSPA (Figura 1A e B); a produção na parte radicular apresentou comportamento oposto, aumentando a produtividade com o aumento nas concentrações de soro de leite. Com base no modelo ajustado, a estimativa da produção de MFPA obtida com soro diluído a $20 \%$ foi de $1,639 \mathrm{~kg} \mathrm{~m}^{-2}$, enquanto com soro não diluído (100\%) foi de $0,415 \mathrm{~kg} \mathrm{~m}^{-2}$, uma queda de $74,7 \%$.

Extrapolando-se tais valores para produtividade por hectare, as plantas cultivadas com soro de leite diluído a $20 \%$ produziram $16,39 \mathrm{t} \mathrm{ha}^{-1}$ somente da parte aérea em um único ciclo de cultivo. Admitindo que se possa realizar mais de 20 ciclos de cultivo por ano, é possível conseguir $300 \mathrm{t} \mathrm{ha}^{-1}$ (matéria fresca). A literatura (FAO, 2001) menciona que é possível se obter, em um ano, mais de 2.000 tha $^{-1}$ de massa fresca, somando-se a massa fresca da parte aérea com a massa fresca do sistema radicular. Extrapolações do presente trabalho atingem o valor de 128,9t ha $^{-1}$ somente em um ciclo de produção, obtendo-se, em um ano, aproximadamente $2.578 \mathrm{t} \mathrm{ha}^{-1}$ ano $^{-1}$ (parte aérea mais raízes e substrato).

Em comparação com a testemunha, a produção de forragem hidropônica (MFPA e MSPA) com soro de leite foi significativamente menor em todas as doses avaliadas (Tabela 2); este resultado demonstra que o emprego direto e exclusivo do soro em concentração igual ou superior a $20 \%$ foi incapaz de reproduzir o mesmo rendimento que se pode obter com uma solução nutritiva balanceada, preparada mediante fertilizantes solúveis.

Na massa fresca e seca total (folha+colmo+substrato+raízes), a testemunha obteve produção 11,79 e $2,10 \mathrm{~kg} \mathrm{~m}^{-2}$, respectivamente, ultrapassando o resultado de massa fresca $\left(9,05 \mathrm{~kg} \mathrm{~m}^{-2}\right)$ encontrado por Müller et al. (2006), cultivando trigo hidroponicamente, com soluções nutritivas preparadas com sais fertilizantes.

O acúmulo da massa fresca do sistema radicular (MFPR) tendeu a aumentar até as concentrações intermediárias de soro, seguindo-se uma redução nas concentrações mais elevadas; a dose de soro de leite que proporcionaria a maior produção de MFPR foi estimada em 73,15\%, com base na derivada do modelo ajustado; esse comportamento quadrático pode ser explicado pela progressiva incorporação de sólidos no substrato à medida em que se aumentou a concentração de soro de leite, ocorrendo, como contrapartida desse aumento, a diminuição da produção de raízes; por outro lado, deve-se registrar que houve diminuição no consumo hídrico e, consequentemente, no volume de solução aplicada (Figura 2), razão pela qual é possível que tenha ocorrido menos incorporação de sólidos no substrato com o acréscimo das doses de soro de leite.

Comercialmente, a forragem hidropônica é fornecida como o conjunto planta mais substrato. No presente trabalho o aumento da produção de MFPR até os níveis intermediários de concentração de soro deve ser tomado com ressalva pois não apresentam necessariamente, os níveis de maior produção de forragem; o acúmulo de massa no bagaço representa também a incorporação dos sólidos dissolvidos e materiais em suspensão no soro do leite, havendo substâncias orgânicas que podem depreciar a qualidade físico-química e organoléptica do substrato. Não foi objetivo deste trabalho a abordagem do efeito do soro na qualidade organoléptica da mistura do substrato com as raízes.

Tabela 2. Contraste entre massa fresca da parte aérea (MFPA) e massa seca da parte aérea (M SPA) e teores de nutrientes na parte aérea das plantas testemunha e das plantas cultivadas com soro de leite

\begin{tabular}{|c|c|c|c|c|c|c|c|c|c|c|c|c|c|c|}
\hline & MF & MS & $\mathbf{N}$ & $\mathbf{P}$ & $\bar{K}$ & $\mathrm{Ca}$ & $\mathrm{Mg}$ & 5 & $\mathrm{Na}$ & $\mathrm{Fe}$ & $\mathrm{Cu}$ & $\mathrm{Zn}$ & $M n$ & $\mathrm{Cl}$ \\
\hline & \multicolumn{2}{|c|}{$\mathrm{kg} \mathrm{m}^{-2}$} & \multicolumn{7}{|c|}{$\mathrm{g} \mathrm{kg}^{-1}$} & \multicolumn{5}{|c|}{$\mathrm{mg} \mathrm{kg}^{-1}$} \\
\hline Test & 2,03 & 0,30 & 28,30 & 9,28 & 5,06 & 5,36 & 3,66 & 2,82 & 0,93 & 118,71 & 26,14 & 86,45 & 62,80 & 7,78 \\
\hline $\mathrm{T} 20$ & $1,64 * *$ & $0,25 * *$ & $26,51^{\text {ns }}$ & $8,78^{\text {ns }}$ & $46,36 * *$ & $4,57^{*}$ & $3,47^{\text {ns }}$ & $2,61^{\mathrm{ns}}$ & $1,14^{\text {ns }}$ & $95,63^{*}$ & $23,31^{*}$ & $98,24^{\text {ns }}$ & $22,20 * *$ & $26,94 * *$ \\
\hline $\mathrm{T} 40$ & $1,39 * *$ & $0,23 * *$ & $27,08^{\text {ns }}$ & $8,83^{\text {ns }}$ & $44,46 * *$ & $3,62 * *$ & $3,47^{\mathrm{ns}}$ & $2,91^{\mathrm{ns}}$ & $2,26 * *$ & $93,08^{*}$ & $21,40 * *$ & $98,88^{\text {ns }}$ & $15,81^{* *}$ & $27,59 * *$ \\
\hline $\mathrm{T} 60$ & $0,97 * *$ & $0,19 * *$ & $30,40^{\text {ns }}$ & $9,08^{\text {ns }}$ & $44,14 * *$ & $2,84 * *$ & $2,83^{* *}$ & $3,44^{*}$ & $3,55^{* *}$ & $88,13^{* *}$ & $22,08^{* *}$ & $106,74^{* *}$ & $15,63 * *$ & $25,48^{* *}$ \\
\hline T80 & $0,68 * *$ & $0,16^{* *}$ & $32,30 *$ & $8,02 * *$ & $43,59 * *$ & $3,01^{* *}$ & $2,50 * *$ & $3,56 *$ & $4,23 * *$ & $88,17^{* *}$ & $23,14 *$ & $101,24^{*}$ & $16,84^{* *}$ & $24,80 * *$ \\
\hline $\mathrm{T} 100$ & $0,46 * *$ & $0,16 * *$ & $34,21 * *$ & $8,64^{\text {ns }}$ & $41,65 * *$ & $2,97 * *$ & $2,59 * *$ & $4,18 * *$ & $4,98 * *$ & $103,69^{\text {ns }}$ & $23,89^{\text {ns }}$ & $116,89 * *$ & $17,26 * *$ & $22,65^{* *}$ \\
\hline C.V. & 13,08 & 10,45 & 7,75 & 6,45 & 6,80 & 15,37 & 10,57 & 13,06 & 18,94 & 15,81 & 9,32 & 10,73 & 9,27 & 6,68 \\
\hline
\end{tabular}

ns, $*, * *$ representam, res pectivamente, não significância e significância a $1 \%$ e a $5 \%$ de probabilidade 


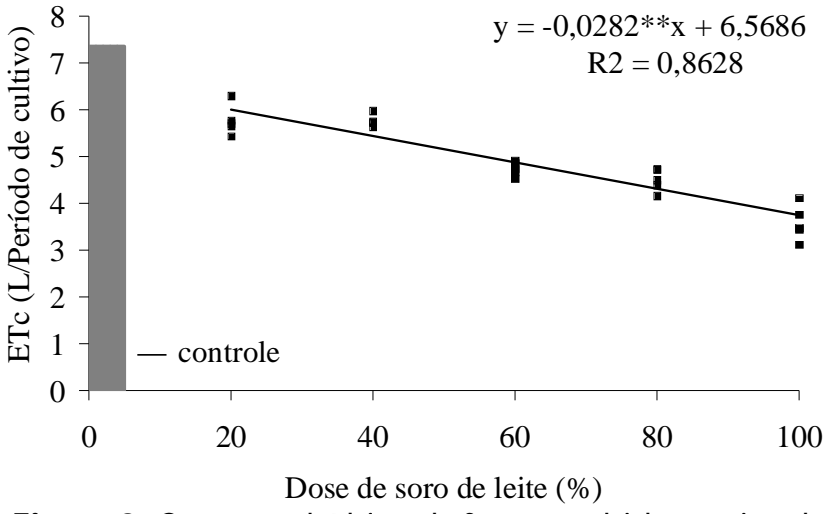

Figura 2. Consumo hídrico da forragem hidropônica de milho em função das diferentes doses de soro de leite utilizadas na solução de cultivo

As plantas irrigadas com $20 \%$ de soro não apresentaram diferença significativa na produção de MFPR em relação à solução testemunha (Tabela 3). Em análise visual observouse, na colheita, que as plantas submetidas às maiores doses de soro apresentaram menos raízes, significando que doses elevadas de soro implicam em maior produção de MFPR por incremento da incorporação de resíduos no substrato e não necessariamente pelo próprio crescimento das raízes.

Com o aumento das doses de soro de leite, notou-se acréscimo linear nos teores de $\mathrm{N}$ da parte aérea havendo tendência quadrática na parte radicular do milho hidropônico (Figura 3A).

De acordo com o teor de proteína bruta encontrado por Müller et al. (2006a) (18,25\%) no cultivo de milho hidropônico produzido aos 10 dias, admite-se teor de $\mathrm{N}$ de $29,2 \mathrm{~g} \mathrm{~kg}^{-1}$, semelhante ao resultado encontrado na parte aérea, ou seja, semelhante ao de Amorim et al. (2005) que detectaram teor de $13,1 \%$ de proteína bruta na parte aérea da forragem hidropônica de milho, produzida aos 28 dias, utilizando-se, como substrato, bagaço de cana, podendo-se admitir, então, teor de N de 20,96 $\mathrm{g} \mathrm{kg}^{-1}$. Segundo Lara Cabezas et al. (2004) em plantas de milho há uma intensa absorção de $\mathrm{N}$ nas fases iniciais de desenvolvimento.

O soro de leite não proporcionou efeito significativo sobre os teores de P na parte aérea da forragem enquanto na porção radicular houve redução significativa e linearmente, em resposta às doses crescentes de soro. Os teores de $\mathrm{P}$ na parte aérea foram mais elevados que nas raízes devido, certamente, ao fato de que as raízes foram analisadas conjuntamente com o substrato, que é pobre neste nutriente mineral, como constataram Rodrigues et al. (2008).

Os teores de $\mathrm{P}$ na parte aérea das plantas submetidas ao soro de leite, com exceção do teor encontrado na solução com $80 \%$ de soro, não foram estatisticamente diferenciados do teor registrado com o uso de solução nutritiva convencional (Tabela 2), em que se pode admitir que o soro do leite proporcione $\mathrm{P}$ suficiente para produção hidropônica de milho; portanto, o cultivo de milho hidropônico com diluições de 20, 40, 60 e $100 \%$ pode proporcionar teores de $\mathrm{P}$ equivalentes aos da solução nutritiva.

Os teores de $\mathrm{K}$ na parte aérea da forragem mostraram-se estáveis ao longo dos tratamentos com soro, ocorrendo um acréscimo suave $(\mathrm{P}<0,01)$ nos teores deste macronutriente, na parte radicular (Figura 3E). As plantas nutridas com solução nutritiva convencional (testemunhas) apresentaram 5,05 $\mathrm{g} \mathrm{kg}^{-1}$ de K na parte aérea; em contrapartida, as plantas tratadas com soro apresentaram mais de oito vezes $\mathrm{K}$ na parte aérea do que as testemunhas, cujos resultados podem acarretar em uma competição com outros cátions, como o Ca e $\mathrm{Mg}$.

Os teores de Ca e Mg na parte aérea apresentaram o mesmo comportamento observado com o P, isto é, redução linear e acréscimo linear nas raízes (raiz + substrato), em resposta ao aumento nas doses de soro (Figura 3D, B). A salinidade do meio de cultivo pode ter afetado os teores de $\mathrm{Ca}$ nas folhas, efeito semelhante ao observado por Garcia et al. (2007), em que o aumento da salinidade ocasionou decréscimos nos teores de Ca.

É provável que o aumento nos teores dos nutrientes na raiz, juntamente com o bagaço de cana (Figura 3D, E) tenha ocorrido não necessariamente pela absorção dos nutrientes e incorporação ao tecido radicular, mas devido ao acúmulo de sólidos totais agregados ao substrato, em virtude do reaproveitamento da solução de cultivo empregada, e à concentração ocorrida em razão da diminuição na evapotranspiração.

A diminuição nos teores de $\mathrm{Ca}$ e $\mathrm{Mg}$ na parte aérea pode ser atribuída ao antagonismo com o K e com o Na (Prado, 2008), nutrientes estes absorvidos em proporções elevadas; ainda que o teor de $\mathrm{K}$ na parte aérea tenha diminuído com o aumento da dose de soro de leite, deve-se ponderar que esse nutriente foi destacadamente absorvido, sendo que seu teor na forragem, obtida com a menor dose de soro (20\%) foi cerca de nove vezes superior ao obtido com a testemunha; já o íon $\mathrm{Na}$ aumentou linearmente na forragem à medida em que se elevou a dose de soro (Figura 5A e B).

Tabela 3. Contraste entre massa fresca da parte aérea (M FPR) e massa seca da parte aérea (M SPR) e teores de nutrientes na parte radicular das plantas testemunhas e das plantas cultivadas com soro de leite

\begin{tabular}{|c|c|c|c|c|c|c|c|c|c|c|c|c|c|c|}
\hline & $\overline{M F}$ & MS & $\mathbf{N}$ & P & K & $\mathrm{Ca}$ & $\overline{M g}$ & $S$ & $\mathrm{Na}$ & $\mathrm{Fe}$ & $\mathrm{Cu}$ & $\mathrm{Zn}$ & $\overline{M n}$ & $\mathrm{Cl}$ \\
\hline & \multicolumn{2}{|c|}{$\mathrm{kg} \mathrm{m}^{-2}$} & \multicolumn{7}{|c|}{$\mathrm{g} \mathrm{kg}^{-1}$} & \multicolumn{5}{|c|}{$\mathrm{mg} \mathrm{kg}^{-1}$} \\
\hline Test & 9,76 & 1,80 & 18,84 & 2,37 & 2,81 & 1,47 & 0,85 & 1,05 & 2,85 & 241,72 & 12, & 241,72 & 1,14 & 3,89 \\
\hline $\mathrm{T} 20$ & $11,25^{\mathrm{ns}}$ & $1,90^{*}$ & $19,73^{\text {ns }}$ & $4,80 * *$ & $6,54 * *$ & $2,59 *$ & $1,10^{*}$ & $1,05^{\text {ns }}$ & $2,93^{\text {ns }}$ & 19 & & $4 *$ & & $5,30 *$ \\
\hline T40 & $13,82^{* *}$ & $1,85^{\text {ns }}$ & $22,55^{* *}$ & $6,22 * *$ & $11,74^{* *}$ & $3,02 * *$ & $1,18^{*}$ & $1,07^{\text {ns }}$ & $5,41 * *$ & $199,44^{\text {ns }}$ & 18, & $199,44^{\text {ns }}$ & $0,83 * *$ & $10,06 * *$ \\
\hline T60 & $13,29 * *$ & $1,88^{\text {ns }}$ & $22,21 * *$ & $6,49 * *$ & $13,77^{* *}$ & $3,78 * *$ & $1,36 * *$ & $1,08^{*}$ & $5,84 * *$ & $190,29 *$ & $13,71^{\text {ns }}$ & $190,29 *$ & $0,87 * *$ & $10,61^{* *}$ \\
\hline T80 & $13,59 * *$ & $1,91^{*}$ & $22,61 * *$ & $6,21 * *$ & $16,78^{* *}$ & $4,27 * *$ & $1,23 * *$ & $1,08^{*}$ & 5,7 & $213,96^{\text {ns }}$ & & $213,96^{\mathrm{ns}}$ & $0,76 * *$ & $11,29 * *$ \\
\hline T100 & $13,48^{* *}$ & $1,91^{*}$ & $21,98 *$ & $5,91 * *$ & $18,10^{* *}$ & $4,56 * *$ & $1,57 * *$ & $1,08^{\text {ns }}$ & $6,43 * *$ & $171,34 * *$ & 18, & $182,31 * *$ & $0,55^{* *}$ & $12,73^{* *}$ \\
\hline C.V. & 9,62 & 3,71 & 8,70 & 10,93 & 6,80 & 17,95 & 15,05 & 1,80 & 8,39 & 13,52 & 14,17 & 13,81 & 11,78 & 10,61 \\
\hline
\end{tabular}

ns, $*, * *$ representam, respectivamente, não significância e significância a $1 \%$ e a $5 \%$ de probabilidade 
A.

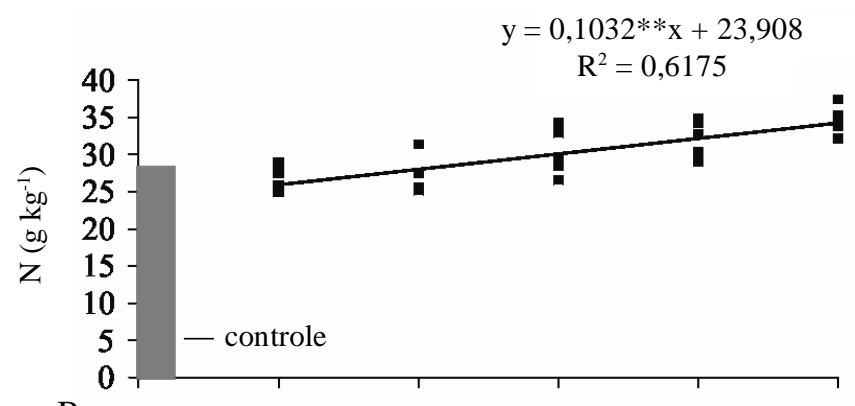

B.

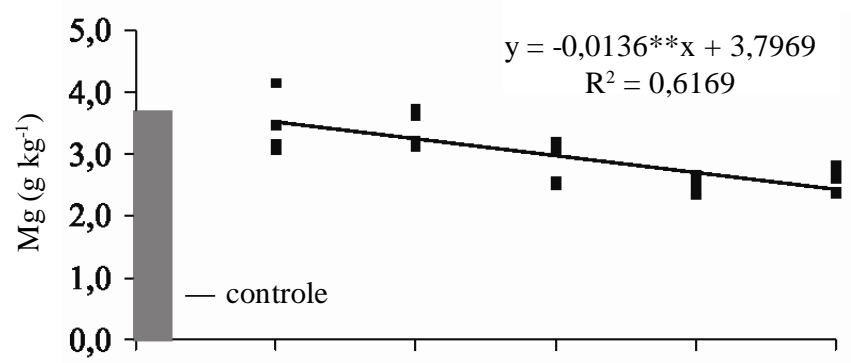

C.

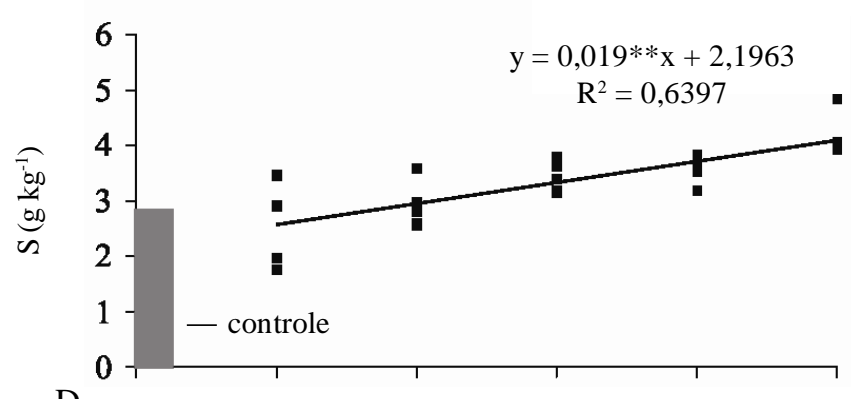

D.

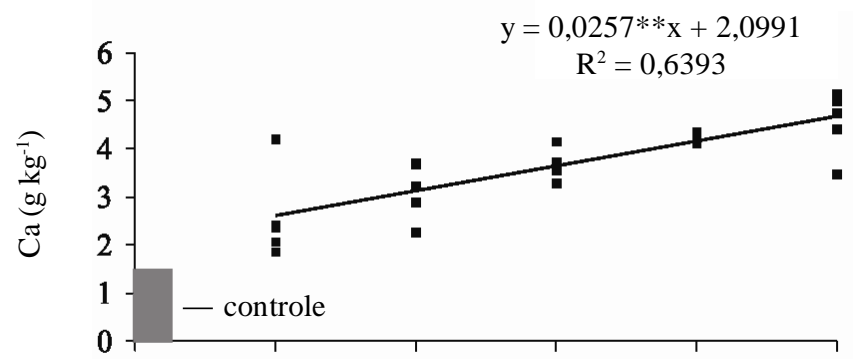

E

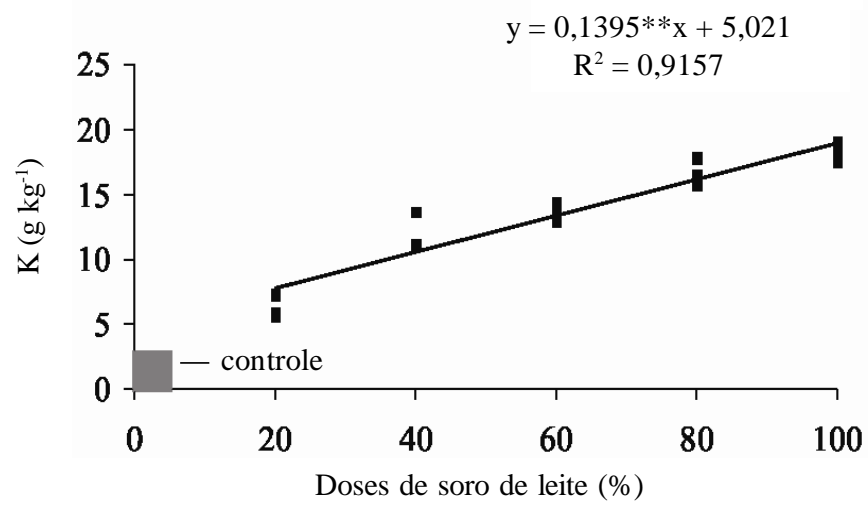

Figura 3. Teores de $N(A), M g(B)$ e $S(C)$ na parte aérea e, $\mathrm{Ca}$ (D) e K (E) na parte radicular da forragem hidropônica de milho, em função das doses de soro de leite utilizadas na solução de cultivo
Os teores de enxofre aumentaram significativamente na porção aérea (Figura 3C), enquanto na porção radicular (raiz + substrato) não houve efeito significativo; os teores de $\mathrm{S}$ na forragem de milho cultivado com 20 e $40 \%$ de soro de leite não diferem estatisticamente da solução convencional, apresentando efeito semelhante ao encontrado com o uso da solução testemunha (Tabela 2).

Os teores de $\mathrm{N}$ e $\mathrm{S}$ na forragem submetida às maiores concentrações de soro foram superiores aos obtidos com a solução nutritiva testemunha, revelando que o soro do leite pode prover $\mathrm{N}$ e $\mathrm{S}$ para o milho hidropônico a partir de suas formas assimiláveis pelas plantas, mas se deve atentar para eventuais efeitos de antagonismo sobre outros nutrientes. Segundo Rodrigues (2002), aumentando a concentração de sulfato a absorção de molibdênio é reduzida e o mesmo ocorre com outros nutrientes quando a concentração de sulfato e P é aumentada.

A análise de regressão não mostrou efeito significativo do soro de leite sobre os teores de Fe na parte aérea e no sistema radicular; contudo, as plantas cultivadas com soro a $20 \%$ já se mostraram significativamente superiores às testemunhas, no que se refere ao acúmulo de $\mathrm{Fe}$, tanto na parte aérea como nas raízes.

As plantas irrigadas com as soluções de menores concentrações de soro de leite (20 e 40\%) apresentaram, na parte aérea, diferença altamente significativa nos teores de $\mathrm{Fe}$ $(\mathrm{P}<0,01)$ em relação à solução convencional; no entanto, a solução composta de $100 \%$ de soro de leite não diferiu da solução controle, o que pode ser atribuído à maior concentração atrelada ao reaproveitamento da solução empregada com intensa absorção pela planta (100\%), visto que em sua composição o teor de $\mathrm{Fe}$ se mostra bastante superior ao constituído na solução nutritiva; os teores de $\mathrm{Fe}$ obtidos nas folhas de milho, que variam entre 88,2 a $118,8 \mathrm{mg} \mathrm{kg}^{-1}$, estão de acordo com os teores (50 a $250 \mathrm{mg} \mathrm{kg}^{-1}$ ) considerados adequados para a cultura do milho (Cavalcante, 2008). Os teores de ferro na parte radicular do milho hidropônico foram significativamente inferiores nos tratamentos com 20, 60 e $100 \%$ de soro, comparando-se com as plantas testemunhas (Tabela 3).

A análise de regressão também não mostrou efeito significativo do soro sobre os teores de Cu na parte aérea e de $\mathrm{Zn}$ nas raízes (raízes+substrato). Com o aumento das doses de soro de leite, observou-se um acréscimo linear nos teores de $\mathrm{Cu}$ na porção radicular e de $\mathrm{Zn}$ na parte aérea. Os teores de Mn, tanto na parte aérea como nas raízes, seguiram tendência quadrática (Figura 4A e B). Os teores de Cu na parte aérea das plantas se encontram ligeiramente acima do teor considerado adequado (6 a $20 \mathrm{mg} \mathrm{kg}^{-1}$ ) para a cultura do milho (Cavalcante, 2008), não ocorrendo diferença significativa entre as doses avaliadas; contudo e se comparando a testemunha com as plantas irrigadas com soro, apenas a dose mais elevada não diferiu significativamente da testemunha (Tabela 2); por outro lado, apenas as plantas tratadas com soro diluído 20 e $60 \%$ não diferiram significativamente da testemunha.

A forragem de milho obteve aumento significativo $(\mathrm{P}<0,01)$ nos teores de $\mathrm{Zn}$ na parte aérea, em resposta às doses de soro de leite. Tanto as plantas testemunhas como as tratadas com 
A.

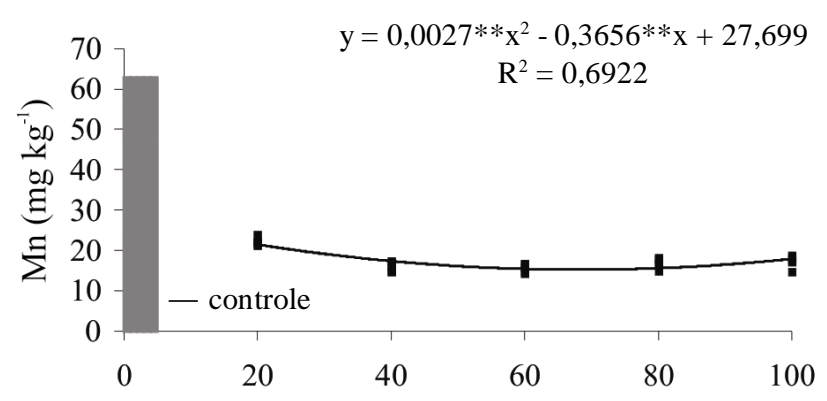

B.

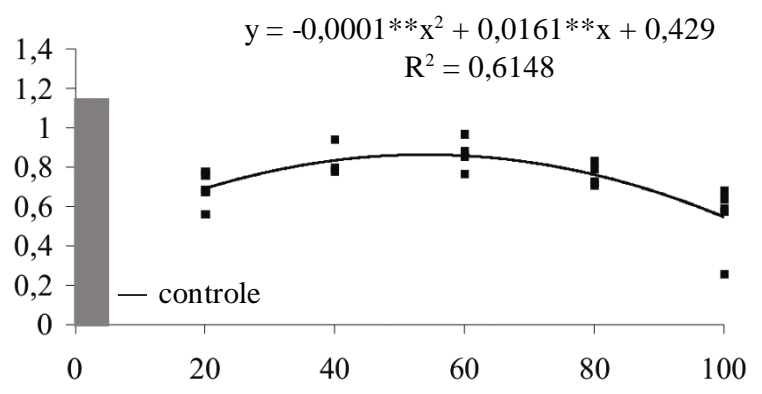

Doses de soro de leite $(\%)$

Figura 4. Teores de $M n$ na parte aérea $(A)$ e da parte radicular (B) da forragem hidropônica de milho, em função das doses de soro de leite utilizadas na solução de cultivo

A.

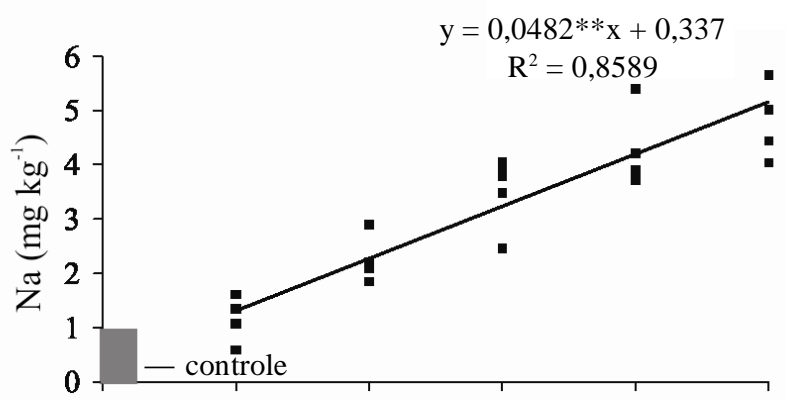

B.

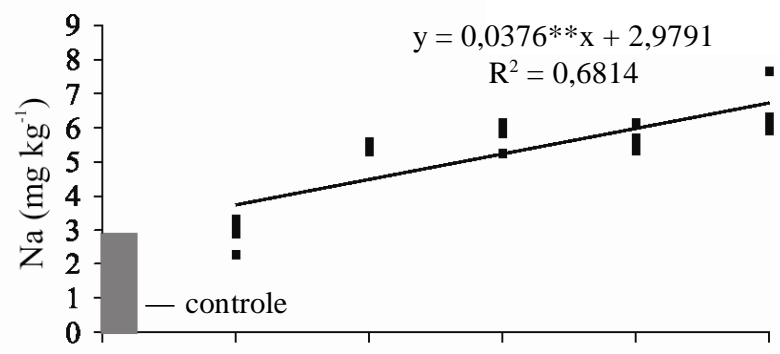

C.

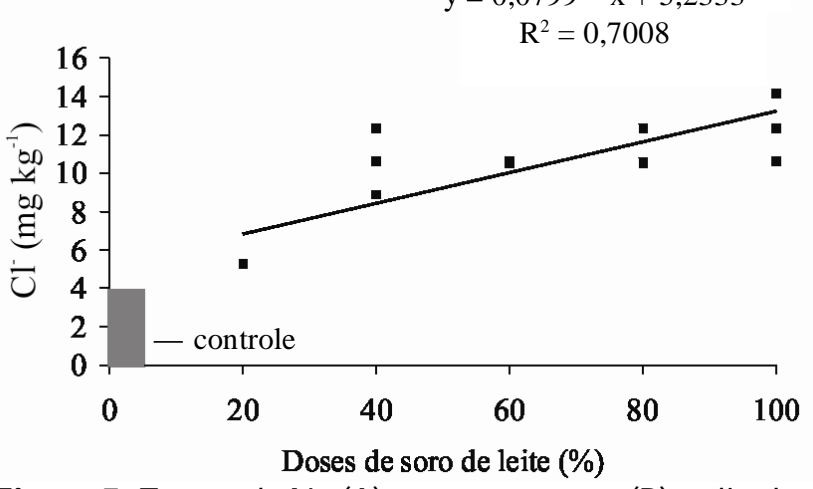

Figura 5. Teores de $\mathrm{N}$ a $(\mathrm{A})$ na parte aérea e $(\mathrm{B})$ radicular e $\mathrm{Cl}^{-}$(C) na parte radicular da forragem de milho hidropônico, em função das doses de soro de leite

soro apresentaram teores de Zn na parte aérea bem mais elevados (acima de $86 \mathrm{mg} \mathrm{kg}^{-1}$ ) que os teores considerados adequados (15 a $50 \mathrm{mg} \mathrm{kg}^{-1}$ ) para folhas de milho (Cavalcante, 2008). Na porção radicular todos os valores obtidos foram superiores a $190 \mathrm{mg} \mathrm{kg}^{-1}$ (Tabela 3), promovendo maior absorção do nutriente pela planta, como resultado de maior quantidade acumulada nas raízes, observando-se que a maior parte do $\mathrm{Zn}$ se acumulou na raiz sendo translocado para a parte aérea da planta (Saraiva et al., 2007), resultado que chama a atenção para o risco de fitotoxidez e desequilíbrios nutricionais (Mann et al., 2001).

Os teores de Mn nas plantas de milho, na parte aérea ou radicular, seguiram tendência quadrática (Figura 4A e B), em resposta às doses de soro de leite; na parte radicular os teores de manganês foram bastante inferiores aos teores na parte aérea devido, certamente ao baixo teor deste nutriente no substrato, e à participação do substrato no conjunto analisado: substrato mais raízes. Nas forragens, o padrão de concentração de $\mathrm{Mn}$ desejado para bovinos e ovinos é de $25 \mathrm{mg} \mathrm{kg}^{-1}$ (MacPherson, 2000); por outro lado, o grão de milho apresenta reduzido teor de $\mathrm{Mn}$, cerca de quatro vezes menos que a forragem cultivada com $20 \%$ de soro de leite.

Houve um aumento linear e crescente nos teores de $\mathrm{Na}$, tanto na parte aérea quanto na porção radicular da forragem de milho hidropônico, em função das doses de soro de leite (Figura 5A e B). Esta resposta se deve ao elevado teor desse elemento na composição do soro (Tabela 1), onde se encontra presente em forma livre e assimilável, mais de duas vezes superior ao conteúdo de $\mathrm{Mg}$ e bastante superior também ao conteúdo de Ca. Semelhante ao observado neste trabalho, Garcia et al. (2007), observaram aumentos nos teores de sódio nas folhas de milho cultivado em ambientes salinos.

As plantas tratadas com soro a $20 \%$ mostraram-se idênticas em relação aos teores de $\mathrm{Na}$ das plantas testemunha, não diferindo significativamente na parte aérea nem na porção radicular; no entanto, as plantas cultivadas com demais concentrações de soro de leite diferiram da testemunha a $5 \%$ de probabilidade (Tabelas 2 e 3 ).

A maioria das plantas geralmente absorve $\mathrm{Cl}^{-}$em níveis acima do necessário ao seu metabolismo (Ferreira et al., 2007); sendo o cloreto um nutriente essencial requerido apenas em pequenas concentrações, quando presente nas plantas em teores elevados causa problemas de toxidez (Prado, 2008). Os teores encontrados nas folhas de milho atingiram níveis que podem levar a facilitar sua ocorrência à toxicidade, além de ocasionar efeitos antagônicos. Observou-se decréscimo nos teores de $\mathrm{Cl}^{-}$na parte aérea e aumento na parte radicular (Figura 5C), em 
resposta às doses de soro; tanto na parte aérea como nas raízes, os teores de $\mathrm{Cl}^{-}$foram significativamente superiores nas plantas cultivadas com soro em comparação com as testemunhas. Ferreira et al. (2007), ao cultivar plântulas de milho em ambientes com elevada salinidade, também observou aumento nos teores de cloreto.

\section{Conclusões}

1. É viável substituir a solução nutritiva por soro de leite diluído a $20 \%$ em água de abastecimento, na produção de forragem hidropônica de milho.

2. É inviável produzir forragem hidropônica de milho com $100 \%$ de soro, em substituição à solução nutritiva convencional.

3. A substituição da solução nutritiva no cultivo da forragem hidropônica de milho por soro de leite a $20 \%$, não compromete os teores dos nutrientes $\mathrm{N}, \mathrm{P}, \mathrm{Mg}, \mathrm{S}, \mathrm{Cu}$ e $\mathrm{Zn}$ na planta.

4. A forragem hidropônica cultivada em soro de leite absorve menos Mn do que cultivada em solução nutritiva convencional.

5. Os elevados teores de $\mathrm{Na}$ e $\mathrm{K}$ no soro de leite provocam redução na produção da forragem de milho hidropônico.

\section{LITERATURA CITADA}

Almeida, K. E.; Bonassi, I. A.; Roça, R. O. Características físicas e químicas de bebidas lácteas fermentadas e preparadas com soro de queijo minas frescal. Ciência e Tecnologia de Alimentos, v.21, p.187-192, 2001.

Amorim, D. M. B.; Notaro I. A.; Furtado D. A.; Gheyi H. R.; Baracuhy J. G. de V. Avaliação de diferentes níveis de salinidade da água utilizada na produção de forragem hidropônica de milho. Revista Brasileira de Engenharia Agrícola e Ambiental, v.9, p.339-342, 2005.

Bezerra Neto, E.; Barreto, L. P. Métodos de análises químicas em plantas. Recife: UFRPE, 2004. 148p.

Brown, M. J.; Robbins, C. W.; Freeborn, L. L. Combining cottage cheese whey and straw reduces erosion while increasing infiltration in furrow irrigation. Journal of Soil and Water Conservation, v.53, p.152-156, 1998.

Cavalcante, F. J. A. (Coord.). Recomendações de adubação para o Estado de Pernambuco: 2a. aproximação. 3.ed. rev. Recife: IPA, 2008. 212p.

Dias, N. da S.; Brito, A.A.F.; Sousa Neto, O. N.; Lira, R. B.; Brito, R. F. Produção de alface hidropônica utilizando biofertilizante como solução nutritiva. Revista Caatinga, v.22, p.158-162, 2009.

FAO - Organización de la Naciones Unidas Para la Agricultura Y Alimentación. Forraje Verde Hidropónico. Oficina Regional de la FAO para América Latina y el Caribe. Manual Técnico. Primera Parte, 2001, 68p.

Fernandes, A. L. T.; Testezlaf, R. Fertirrigação na cultura do melão em ambiente protegido, utilizando-se fertilizantes organominerais e químicos. Revista Brasileira de Engenharia Agrícola e Ambiental, v.16, p.122-126, 2002.
Ferreira, P. A.; Garcia, G. O.; Neves, J. C. L.; Miranda, G. V.; Santos, D. B. Produção relativa do milho e teores folheares de nitrogênio, fósforo, enxofre e cloro em função da salinidade do solo. Revista Ciência Agronômica, v.38, p.7$16,2007$.

Florentino, E. R. Aproveitamento do soro de queijo na produção de etanol visando minimizar seu impacto ambiental. In. Simpósio Luso-Brasileiro de Engenharia Sanitária e Ambiental, 11, 2004, Natal. Anais... Natal: Sibelusa, 2004, CD-Rom

Garcia, G. O.; Ferreira, P. A.; Miranda, G. V.; Neves, J. C. L.; Moraes, W. B.; Santos, D. B. dos. Teores foliares dos macronutrientes catiônicos e suas relações com o sódio em plantas de milho sob estresse salino. Idesia, v.25, p.93-106, 2007.

Ghaly, A. E.; Kamal, M. A. Submerged yeast fermentation of acid cheese whey for protein production and pollution potential reduction. Water Research, v.38, p.631-644, 2004.

Gheri, E. O.; Ferreira, M. E.; Cruz, M. C. P. Resposta do capim Tanzânia a aplicação de soro ácido de leite. Pesquisa Agropecuária Brasileira, v.38, p.753-760, 2003.

Gomes, J. W. S.; Dias, N. da S.; Oliveira, A. M.; Blanco, F. F.; Sousa Neto, O. N. Crescimento e produção de tomate cereja em sistema hidropônico com rejeito de dessalinização. Revista Ciência Agronômica, v.42, p.1-5, 2011.

Gonella, C.; Pérez, L.; Hernández, R.; Homse, A.; Gómez, P.; Rosso, O. Producción de carne em sistemas ecológicos. Revista de Informacion sobre Investigacion y Desarrollo Agropecuário, v.2, p.73-78, 2002.

Hosseini, M.; Shojaosadati, S. A.; Towfighi, J. Application of a bubble-column reactor for the production of a single-cell protein from cheese whey. Chemical Engineering Research, v.42, p.764-766, 2003.

Haraguchi, F. K.; Abreu, W. C.; Paula, H. Proteínas do soro do leite: composição, propriedades nutricionais, aplicações no esporte e benefícios para a saúde humana. Revista de Nutrição, v.19, p.479-488, 2006.

Lara Cabezas, W. A. R.; Alves, B. J. R.; Urquiaga,S.; Santana, D. G. de. Influência da cultura antecessora e da adubação nitrogenada na produtividade de milho em sistema plantio direto e solo preparado. Ciência Rural, v.34, p.1005-1013, 2004.

Lehrsch, G. A.; Robbins, C. W.; Brown, M. J. Whey utilization in furrow irrigation: Effects on aggregate stability and erosion. Bioresource Technology, v.99, p.8458-8463, 2008.

Keller, R. P.; Perin, K.; Souza, W. G.; Cruz, L. S.; Zandonade, E.; Cassini, S. T.; Goncalves, R. F. Use of polishing pond effluents to cultivate lettuce (Latuca sativa) in hidroponic system. Water Science and Technology, v.58, p.21-27, 2008.

MacPherson, A. Trace-mineral status forages. In: Givens, D. J.; Owens, E.; Axford, R. F. E.; Omed, H. M. Forage evaluation in ruminant nutrition. Wallingford: CABI, 2000. p.345-371.

Mann, E. N.; Rezende, P. M.; Carvalho, J. G.; Corrêa, J. B. D. Efeito da adubação com manganês, via solo e foliar em diferentes épocas na cultura da soja [Glycine max (L.) Merril]. Revista Ciência Agrotécnica, v.25, p.264-273, 2001. 
Müller, L.; Manfron, P. A.; Medeiros, S. L. P.; Santos, O. S.; Morselli, T. B. G. A.; Dourado Neto, D.; Fagan, E. B.; Bandeira, A. H.; Tonetto, C. J. Valor nutricional da forragem hidropônica de trigo sob diferentes soluções nutritivas. Bioscience Journal, v.22, p.49-56, 2006a.

Müller, L.; Santos, O. S.; Manfron; P. A.; Medeiros, S. L. P.; Haut, V.; Dourado Neto, D.; Menezes, N. L. de; Garcia, D. C. Forragem hidropônica de milheto: produção e qualidade nutricional em diferentes densidades de semeadura e idades de colheita. Ciência Rural, v.36, p.1094-1099. 2006 b.

Prado, R. M. Nutrição de plantas. São Paulo: UNESP, 2008. 408p.

Reis, G. L. Sistema de gestão ambiental em laticínios. Revista Cândido Tostes, v.54, p.35-47, 1999.

Rodrigues, A. A.; Cruz, G. M.; Batista, L. A. R.; Pedroso A. F.; Landell, M. G. A.; Anjos I. A. Teores de minerais em variedades de cana-de-açúcar com potencial para alimentação de bovinos. Ciência Agrotécnica, v.32, p.13591365, 2008.

Rodrigues, L. R. F. Técnicas de cultivo hidropônico e de controle ambiental no manejo de pragas, doenças e nutrição vegetal em ambiente protegido. 1.ed. Jaboticabal: FUNEP, 2002. 762p.

Santin, M. M.; Santos, H. S.; Scapim, C. A.; Brandão Filho, Torres J. U.; Callegari, O.; Santos, A. A. J.; Santos, I. A. Relação entre substratos e métodos de aplicação de solução nutritiva na produção de mudas e posterior resposta produtiva da beterraba. Acta Scientiarum, v.27, p.423-432, 2005.
Santos, A. N.; Soares, T. M.; Silva, E. F. de F.; Silva, D. J. R. e; Montenegro, A. A. A. Cultivo hidropônico de alface com água salobra subterrânea e rejeito da dessalinização em Ibimirim, PE. Revista Brasileira de Engenharia Agrícola e Ambiental, v.14, p.961-969, 2010.

Santos, M. E.; Zanine, A. M.; Ferreira, D. J.; Oliveira, J. S.; Pereira, O. G.; Almeida, J. C. Efeito da adição do soro de queijo sobre a composição bromatológica, fermentação, perdas e recuperação de matéria seca em silagem de capimelefante. Ciência Animal Brasileira, v.7, p.235-239, 2006.

Saraiva, F. Z.; Sampaio, S. C.; Silvestre, M. G.; Queiroz, M. M. F.; Nóbrega L. H. P.; Gomes, B. M. Uso de manipueira no desenvolvimento vegetativo do milho em ambiente protegido. Revista Brasileira de Engenharia Agrícola e Ambiental, v.11, p.30-36, 2007.

Silva, K.; Bolini, H. M. A.; Antunes, A. J. Soro de leite bovino em sorvete. Alimentos e Nutrição, v.15, p.187-196, 2004.

Soares, T. M.; Silva, I. J. O.; Duarte, S. N.; Silva, E. F. F. Destinação de águas residuárias provenientes de dessalinizadores por osmose reversa. Revista Brasileira de Engenharia Agrícola e Ambiental, v. 10, p.730-737, 2006.

Soares, T. M.; Duarte, S. N.; Silva, E. F. F.; Jorge, C. Combinação de águas doce e salobra para produção de alface hidropônica. Revista Brasileira de Engenharia Agrícola e Ambiental, v.14, p.705-714, 2010.

Villela Júnior, L. V. E.; Araújo, J. A. C.; Factor, T. L. Comportamento do meloeiro em cultivo sem solo com a utilização de biofertilizante. Horticultura Brasileira, v.21, p.154-158, 2003. 